\title{
When less may be more: calorie restriction and response to cancer therapy
}

\author{
Ciara H. O'Flanagann', Laura A. Smith' ${ }^{1}$, Shannon B. McDonell ${ }^{1}$ and Stephen D. Hursting ${ }^{1,2,3,4^{*}}$
}

\begin{abstract}
Calorie restriction (CR) extends lifespan and has been shown to reduce age-related diseases including cancer, diabetes, and cardiovascular and neurodegenerative diseases in experimental models. Recent translational studies have tested the potential of CR or CR mimetics as adjuvant therapies to enhance the efficacy of chemotherapy, radiation therapy, and novel immunotherapies. Chronic CR is challenging to employ in cancer patients, and therefore intermittent fasting, CR mimetic drugs, or alternative diets (such as a ketogenic diet), may be more suitable. Intermittent fasting has been shown to enhance treatment with both chemotherapy and radiation therapy. $\mathrm{CR}$ and fasting elicit different responses in normal and cancer cells, and reduce certain side effects of cytotoxic therapy. Findings from preclinical studies of CR mimetic drugs and other dietary interventions, such as the ketogenic diet, are promising for improving the efficacy of anticancer therapies and reducing the side effects of cytotoxic treatments. Current and future clinical studies will inform on which cancers, and at which stage of the cancer process, $C R$, fasting, or CR mimetic regimens will prove most effective.
\end{abstract}

Keywords: Calorie restriction, Chemotherapy, Radiation therapy, Ketogenic diet, Fasting, Metabolism, Autophagy, Cachexia, Insulin-like growth factor 1, Drug resistance

\section{Background}

\section{Calorie restriction (CR) and cancer}

$\mathrm{CR}$, a chronic reduction of dietary energy intake by approximately $30 \%$ without incurrence of malnutrition, is a broadly effective dietary intervention that significantly decreases adiposity and inflammation and improves metabolic profiles in non-obese humans and rodents [1-4]. Preclinical studies in mammalian models demonstrate that CR extends lifespan, ameliorates risk factors, and delays onset of age-related diseases, including cancer, type II diabetes, and cardiovascular and neurodegenerative diseases [4]. In response to decreased caloric intake, metabolic alterations foster health promoting characteristics, including increased insulin sensitivity and decreased blood glucose, growth factor signaling, inflammation, and angiogenesis [4]. While the impact of CR on age-related pathologies has been studied most extensively in rodent models, data from human observational and randomized

\footnotetext{
* Correspondence: hursting@email.unc.edu

'Department of Nutrition, University of North Carolina, Chapel Hill, NC 27517, USA

${ }^{2}$ Lineberger Comprehensive Cancer Center, University of North Carolina,

Chapel Hill, NC 27517, USA

Full list of author information is available at the end of the article
}

clinical trials demonstrate that $\mathrm{CR}$ in non-obese humans results in metabolic and molecular changes similar to those observed in rodent models [5]. Within the scope of cancer research, a meta-analysis of preclinical rodent models evaluated the impact of CR across multiple cancer types and through a variety of tumor models [6]; overall, CR displayed a $75.5 \%$ reduction in tumor incidence. Longitudinal studies at the National Institute of Ageing and the University of Wisconsin showed a significant reduction in the incidence of cancers in rhesus monkeys fed a CR diet compared to a control diet [7]. While the antitumorigenic effects of $\mathrm{CR}$ are well established, the mechanism behind this relationship remains unclear, though it is believed that the tumor suppressive effects are mediated, in part, by enhanced apoptosis within tumors, modulation of systemic signals such as insulin-like growth factor (IGF)-1, insulin, metabolic and inflammatory pathways, as well as by reduced angiogenesis.

Exposure to an energy restricted diet results in reduced systemic glucose and growth factors such as IGF-1 [1, 8, 9]. Preclinical studies in breast, pancreatic, and colon cancer have demonstrated that modulation of IGF-1 signaling plays a major role in CR's anticancer 
effects $[8,10,11]$. In alignment with this, population studies have demonstrated that the IGF-1 signaling pathway plays a significant role in the development and progression of many cancer types [12]. IGF-1 is a nutrient-responsive growth factor that activates two major signaling cascades, namely Ras/MAPK and PI3K/AKT. Activation of the Ras/MAPK pathway promotes activity of transcription factors and subsequent expression of genes involved in proliferation and cellular growth. Initiation of the PI3K/AKT pathway promotes decreased apoptosis by disrupting the BCL2-Bad complex, increases protein synthesis via mTOR activation, and increases glucose metabolism by inhibiting GSK-3 $\beta$ [13]. Cancer cells utilize the IGF-1 signaling pathway to redirect their metabolic investment towards proliferation and growth, and thus reduction of IGF-1 levels in CR results in decreased tumor growth and progression $[8,10,11]$. Addition of exogenous IGF-1 leads to the partial reversal of the anticancer effects of CR, further supporting the role of IGF-1 in tumorigenesis [10]. In addition, expression of signaling factors downstream of IGF-1 has been correlated with either resistance or sensitivity to several cancer therapies [14]. Nevertheless, although IGF-1 signaling is a promising anticancer target, drugs targeting the pathway have been largely unsuccessful [12].

$\mathrm{CR}$ also induces activation of AMP-activated protein kinase (AMPK), a molecular sensor that increases catabolism and inhibits anabolic metabolism, working in opposition to IGF-1-mediated activation of $\operatorname{mTOR}[4,15]$. AMPK activation in response to CR conditions results in increased apoptosis within brain tumors while protecting normal cells from the stress $[16,17]$. AMPK induces expression of metabolic control genes, including SIRT1, resulting in increased fatty acid oxidation and glutaminolysis to provide auxiliary substrates when glucose is scarce [18]. In line with this, CR results in elevated serum glutamine [19] and ketone bodies [20]. Many tumors undergo metabolic reprogramming, including enhanced fatty acid oxidation and glutaminolysis in addition to increased glucose metabolism [21-23]. Some cancers can therefore become autonomous, uncoupling their growth from the availability of systemic factors under normal conditions. Despite it not being clear whether administration of $C R$ would support tumor growth in these circumstances, it is thought that transformed cells lack the metabolic adaptability to respond to altered substrate availability, having already invested heavily in metabolic reprograming and thus being more sensitive to increased pressure on ketone metabolism and fatty acid oxidation than normal cells [24].

The AMPK/mTOR axis also controls autophagy, a process through which proteins, macronutrients and organelles are enveloped in double-membraned vesicles and degraded into building blocks that can then be shuttled into synthetic pathways. Under CR conditions, AMPK activation stimulates increased autophagy to recycle cellular components and provide needed substrates for metabolism and homeostasis [4, 15]. Autophagy can act as a double-edged sword in cancer - it is thought to be tumor suppressive since defects in autophagy drive oxidative stress, mitochondrial defects, DNA damage, genomic instability, and tumor growth [25]. Conversely, it is believed to be tumor promoting because established tumors can utilize autophagy to reduce oxidative stress and increase mitochondrial function and metabolism in order to promote survival and overcome stress and low nutrient conditions $[25,26]$. Due to the dual role of autophagy in cancer, autophagy inducers and inhibitors have become targets for cancer therapy [27]. Recent research in our lab showed that combining autophagy inhibition with a $C R$ regimen reduced tumor growth more than either treatment alone [20].

Furthermore, increasing preclinical and human evidence suggests that $C R$ reduces inflammation [11, 28, 29]. Multiple inflammatory signaling cascades can promote the growth and survival of neoplastic cells [30]. The reduction of energy intake in $\mathrm{CR}$ reduces the amount of adipose tissue, a major endocrine organ that secretes proinflammatory factors including leptin, adiponectin, monocyte chemo-attractant protein-1, tumor necrosis factor, and interleukin-6 [31]. CR in human studies is associated with reduced adiposity and a lessened inflammatory adipose secretome, as well as particularly decreased systemic levels of pro-inflammatory adipokines [32]. In addition, CR has been shown to consistently reduce the expression of the pro-angiogenic factors vascular endothelial factor $[9,33]$ and plasminogen activator inhibitor-1 [15], both of which induce the growth of new blood vessels to provide growing tumors with oxygen and glucose. CR has also been shown to reduce vascularization of tumors $[9,16]$. In addition to altering systemic inflammatory mediators, CR has been shown reduce the expression of inflammatory genes in cancer cells, including nuclear factor kappa B $[11,34]$ and peroxisome proliferator-activated receptors [35], which are ligand-activated transcription factors involved in regulating inflammation, proliferation, and glucose and lipid homeostasis and often expressed in cancer cells [36, 37].

\section{$\mathrm{CR}$ and therapeutic response}

To date, much of the research into the tumor suppressive effects of $\mathrm{CR}$ relate to the preventative capacity of the intervention, rather than its application as an anticancer therapy. Recent attention has focused on the potential of $C R$ as an adjunct therapy for a range of cancers in combination with traditional chemotherapy or radiation therapy [38]. While chronic CR may be well tolerated in preclinical and clinical studies of healthy 
individuals, patients diagnosed with cancer are at a greater risk of weight loss due to toxic cancer therapies, as well as cachexia and sarcopenia from tumor-derived signals to degrade adipose and muscle tissues, to which chronic CR may contribute. Furthermore, as CR is antiinflammatory, chronic CR may be a concern to patients with immunodeficiency or following surgery. Intermittent $\mathrm{CR}$, achieved through fasting where no calories are consumed for defined periods of time (between $24 \mathrm{~h}$ up to 6 days), causes similar metabolic and anti-inflammatory alterations as seen during chronic $\mathrm{CR}$, and can often result in greater changes in the short term [39]. In contrast to chronic $\mathrm{CR}$, fasting results in glycogen release from the liver for use as an energy source. Once glycogen stores are depleted, amino acids and fatty acids are catabolized to generate glucose and ketone bodies, respectively [39]. Short-term fasting has been shown to improve chemotherapeutic treatment with etoposide [40], mitoxantrone, oxaliplatin [41], cisplatin, cyclophosphamide, and doxorubicin [42] in transgenic and transplant mouse models of neuroblastoma, fibrosarcoma, glioma, melanoma, and breast and ovarian cancers. Alternate day fasting has also been shown to improve the radiosensitivity of mammary tumors in mice $[38,43]$, likely due to enhanced oxidative stress and DNA damage during short-term fasting on cancer cells. Fasting has also been shown to control circadian clock genes, the expression of which usually oscillates at specific intervals throughout the day and is coupled to processes such as oxidative stress response and DNA damage repair [44]. Chemotherapeutic treatment administered at different times of the day has been found to improve efficacy, believed to be due to circadian rhythmic control of stress responses [45]. Fasting may therefore improve the efficacy of anti-cancer therapies in part by controlling the circadian rhythm.

Elegant work by Rafaghello et al. [40] demonstrated that short-term fasting elicits differential responses to chemotherapy in normal and cancer cells, with normal cells inactivating growth signals, such as Ras, Akt and IGF-1, in response to short-term fasting protecting them from therapeutic toxicity. In contrast, cancer cells, which have arisen due to activation of these signals and evasion of senescence-inducing signals, do not undergo this inactivation, remaining vulnerable to cytotoxic treatment via chemotherapy or radiation therapy. The induction of these cancer-specific stress responses may impact mechanisms related to chemoresistance, including multidrug resistance [46].

More recently, a fasting-mimicking diet, in which mice are fed the same amount of food as control mice, albeit with a severely reduced caloric density, showed a similar reduction in tumor growth as short-term starvation and displayed synergistic therapeutic effects when combined with doxorubicin and cyclophosphamide [41, 47]. Cycles of this diet have recently been shown to improve metabolic and inflammatory biomarkers associated with cancer risk in humans [48]. Mechanistically, the synergizing effects of the fasting-mimicking diet were associated with increased autophagy in the cancer cells and reduced heme oxygenase-1 (HO-1) in the microenvironment, causing increased circulating $\mathrm{CD}^{+} \mathrm{T}$ cells and reduced $\mathrm{T}_{\text {reg }}$ cells, and resulting in enhanced immunosurveillance and clearance of tumor cells [41, 47]. Moreover, prolonged cycles of fasting have also been shown to protect immune cells during chemotherapeutic treatment $[49,50]$, suggesting the possibility of combining immunotherapies with traditional chemotherapy alongside such dietary interventions. Similarly, CR also maintains immunological fitness of $\mathrm{CD}_{4}^{+} \mathrm{T}$ cells during aging to enhance cancer immunotherapy, specifically OX40-agonist immunotherapy [50]. In addition, a CR regimen can reduce desmoplasia and the inflammatory microenvironment of tumors [9], previously shown to impede the delivery of therapeutic drugs to the tumor cells.

While preclinical studies are mounting on the effects of intermittent $\mathrm{CR}$ in combination with chemotherapy and radiation therapy, clinical studies are slow to follow, likely due to the concerns listed above. A summary of past and current clinical trials of intermittent CR, fasting-mimicking diets, and ketogenic diets in combination with anticancer therapies is included in Table 1. A small study comprising ten subjects diagnosed with malignancies, including breast, esophageal, prostate, and lung, who underwent a $48-140 \mathrm{~h}$ fast prior to and a $56 \mathrm{~h}$ postchemotherapy fast revealed significant improvement in self-reported side effects of therapy, including nausea, vomiting, diarrhea, weakness, and fatigue [51, 52].

Larger trials are currently underway to determine the potential for short-term fasting in reducing the side effects and efficacy of chemotherapies, and will likely be the launching point for future clinical trials with intermittent $\mathrm{CR}$ as a potential adjuvant therapy.

\section{CR mimetics}

Given the nutritional concerns of $\mathrm{CR}$ and fasting in some cancer patients, CR mimetics, namely pharmacological agents that target pathways affected by $C R$, such as rapamycin, metformin, resveratrol, and hydroxycitrate, are attractive strategies to mimic the protective effects of CR both for cancer prevention and as adjuvant therapies without dietary restriction. These CR mimetics affect systemic and tumor-specific inflammation and metabolism, and targeting these pathways may sensitize cancers to traditional and emerging anti-cancer therapies by reducing tumor-associated inflammation or causing metabolic stress in the cancer cell.

Administration of the CR mimetic rapamycin (sirolimus), an immunosuppressant drug and established inhibitor of 
Table 1 List of ongoing or completed clinical trials including calorie restriction (CR) or CR mimetic diets or drugs in combination with chemotherapy or radiotherapy

\begin{tabular}{|c|c|c|c|c|}
\hline Intervention & Drug treatment(s) & Disease(s) & Reference & $\begin{array}{l}\text { Outcome/Anticipated } \\
\text { completion date }\end{array}$ \\
\hline Fasting-mimicking diet & Standard chemotherapy & Breast & $\begin{array}{l}\text { NCT02126449 } \\
\text { de Groot et al. } 2015 \text { [79] }\end{array}$ & December 2018 \\
\hline Fasting: up to $60 \mathrm{~h}$ & Taxanes & Prostate & NCT02710721 & December 2017 \\
\hline Fasting: up to $48 \mathrm{~h}$ & Standard chemotherapy & Ovarian, breast & NCT01954836 & $\begin{array}{l}\text { Completed, no reported } \\
\text { results }\end{array}$ \\
\hline Fasting: $20-140 \mathrm{~h}$ & $\begin{array}{l}\text { Docetaxel, paclitaxel, } \\
\text { cyclophosphamide, } \\
\text { carboplatin, gemcitabine, } \\
\text { doxorubicin }\end{array}$ & $\begin{array}{l}\text { Breast, esophagus, prostate, } \\
\text { lung, uterine, ovarian }\end{array}$ & $\begin{array}{l}\text { Safdie et al. } 2009 \\
\text { NCT01304251 [52] }\end{array}$ & $\begin{array}{l}\text { Reduced self-reported } \\
\text { side effects }\end{array}$ \\
\hline Fasting: up to $48 \mathrm{~h}$ & Gemcitabine, cisplatin & $\begin{array}{l}\text { Primary and metastatic } \\
\text { lesions }\end{array}$ & NCT00936364 & September 2017 \\
\hline Ketogenic diet & Radiotherapy & Colorectal, breast & NCT02516501 & June 2018 \\
\hline Ketogenic diet & Palliative chemotherapy & Glioblastoma & NCT02939378 & December 2017 \\
\hline Ketogenic diet & Temozolomide & Glioblastoma & NCT02046187 & $\begin{array}{l}\text { Completed, no reported } \\
\text { results }\end{array}$ \\
\hline Ketogenic diet & Temozolomide, radiotherapy & Glioblastoma & NCT02302235 & August 2016, recruiting \\
\hline Ketogenic diet & $\begin{array}{l}\text { Standard chemotherapy, } \\
\text { radiotherapy }\end{array}$ & Glioblastoma & NCT03075514 & March 2018 \\
\hline $\begin{array}{l}\text { Intermittent energy } \\
\text { restriction }\end{array}$ & Docetaxel, paclitaxel & Breast & B-AHEAD-2 & $\begin{array}{l}\text { Completed, no reported } \\
\text { results }\end{array}$ \\
\hline Everolimus & Docetaxel, cisplatin & Head and neck & NCT00935961 & $\begin{array}{l}\text { Completed, no reported } \\
\text { results }\end{array}$ \\
\hline Everolimus & Rituximab & B-cell lymphoma & NCT00790036 & $\begin{array}{l}\text { Completed, no reported } \\
\text { results }\end{array}$ \\
\hline Everolimus & Pemetrexed & Lung & NCT00434174 & $\begin{array}{l}\text { Completed, no reported } \\
\text { results }\end{array}$ \\
\hline Everolimus & Doxorubicin, bevacizumab & Breast & NCT02456857 & $\begin{array}{l}\text { Completed, no reported } \\
\text { results }\end{array}$ \\
\hline Everolimus & Bevacizumab, lapatinib & Breast & NCT00567554 & $\begin{array}{l}\text { Completed, no reported } \\
\text { results }\end{array}$ \\
\hline Everolimus & $\begin{array}{l}\text { Cisplatin, navelbine, } \\
\text { radiotherapy }\end{array}$ & Lung & NCT01167530 & $\begin{array}{l}\text { Completed, no reported } \\
\text { results }\end{array}$ \\
\hline Everolimus & Lenvatinib & Renal & NCT02915783 & December 2018 \\
\hline Sirolimus & Etoposide, cyclophosphamide & $\begin{array}{l}\text { Solid and central nervous } \\
\text { system }\end{array}$ & NCT02574728 & June 2020 \\
\hline Temsirolimus & Bevacizumab & Prostate & NCT01083368 & $\begin{array}{l}\text { Completed, no reported } \\
\text { results }\end{array}$ \\
\hline Temsirolimus & Standard AML chemotherapy & AML & NCT01611116 & July 2017 \\
\hline Temsirolimus & $\begin{array}{l}\text { Dexamethasone, mitoxantrone, } \\
\text { vincristine, PEG-aspargase }\end{array}$ & $\mathrm{AML}, \mathrm{NHL}$ & NCT01403415 & $\begin{array}{l}\text { Completed, no reported } \\
\text { results }\end{array}$ \\
\hline Metformin & Cisplatin, radiotherapy & Lung & NCT02115464 & December 2017 \\
\hline Metformin & $\begin{array}{l}\text { Anthracycline, taxane, platinum, } \\
\text { capecitabine, vinorelbine }\end{array}$ & Metastatic breast & NCT01310231 & March 2016; recruiting \\
\hline Metformin & Radiation, carboplatin, paclitaxel & Lung & NCT02186847 & March 2018 \\
\hline Metformin & $\begin{array}{l}\text { Dexamethasone, mitoxantrone, } \\
\text { vincristine, PEG-aspargase }\end{array}$ & ALL & NCT01324180 & $\begin{array}{l}\text { Completed, no reported } \\
\text { results }\end{array}$ \\
\hline Metformin & 5-Fluorouracil & Colorectal & NCT01941953 & $\begin{array}{l}\text { Completed, no reported } \\
\text { results }\end{array}$ \\
\hline Metformin & $\begin{array}{l}\text { Folfinic acid, oxaliplatin, } \\
\text { leucovorin, 5-fluorouracil, } \\
\text { irinotecan }\end{array}$ & Colorectal & NCT01926769 & $\begin{array}{l}\text { Completed, no reported } \\
\text { results }\end{array}$ \\
\hline
\end{tabular}


Table 1 List of ongoing or completed clinical trials including calorie restriction (CR) or CR mimetic diets or drugs in combination with chemotherapy or radiotherapy (Continued)

\begin{tabular}{|c|c|c|c|c|}
\hline Metformin & Cisplatin, radiotherapy & Head and neck & NCT02949700 & December 2019 \\
\hline Metformin & $\begin{array}{l}\text { Fluorouracil, doxorubicin, } \\
\text { cyclophosphamide }\end{array}$ & Breast & NCT02506777 & November 2015; recruiting \\
\hline Metformin & $\begin{array}{l}\text { Paclitaxel, carboplatin, } \\
\text { docetaxel }\end{array}$ & $\begin{array}{l}\text { Ovarian, fallopian tube, } \\
\text { peritoneal }\end{array}$ & NCT02122185 & February 2018 \\
\hline Metformin & Carboplatin, paclitaxel & Ovarian & NCT02312661 & March 2017 \\
\hline Metformin & Gemcitabine, erlotinib & Pancreatic & NCT01210911 & $\begin{array}{l}\text { Completed, no reported } \\
\text { results }\end{array}$ \\
\hline Metformin & Standard chemotherapy & All tumor types & NCT01442870 & $\begin{array}{l}\text { Completed, no reported } \\
\text { results }\end{array}$ \\
\hline Hydroxycitrate & $\begin{array}{l}\text { Folinic acid, oxaliplatin, } \\
\text { leucovorin, 5-fluorouracil, } \\
\text { irinotecan, cetuximab, vectibix, } \\
\text { carboplatin, bevacizumab, } \\
\text { cisplatin, gemcitabine }\end{array}$ & $\begin{array}{l}\text { Metastatic lung, colon, ovarian, } \\
\text { esophagus, uterine, liver, } \\
\text { parotid, prostate }\end{array}$ & $\begin{array}{l}\text { Schwartz et al. } \\
2014 \text { [68] }\end{array}$ & $\begin{array}{l}\text { Hydroxycitrate is tolerated, } \\
\text { but no added benefit } \\
\text { was found }\end{array}$ \\
\hline
\end{tabular}

$A M L$ acute myeloid leukemia, $A L L$ acute lymphoblastic leukemia, NHL non-Hodgkin's lymphoma

mTOR, extends lifespan and delays cancer in mice [53]. Our lab has shown that rapamycin or its analog, Afinitor ${ }^{\circ}$ (everolimus), can mimic the anticancer effects of CR in mouse models of pancreatic and breast cancer [54, 55]. Signaling via the mTOR pathway has been implicated in a broad range of chemoresistant cancers [56], and rapamycin has been shown to reverse multidrug resistance [57]. Promising preclinical studies demonstrate that rapamycin can sensitize certain cancers to chemotherapy and radiation therapy. Active phase I and II clinical trials are ongoing to determine the effect of combining rapamycin with chemotherapeutic regimens, including gemcitabine for osteosarcoma, cyclophosphamide, dexamethasone in myeloma, and mitoxantrone, etoposide and cytarabine for leukemia.

Another CR mimetic, metformin, is a biguanide commonly used to treat type 2 diabetes by inhibiting gluconeogenesis through indirect activation of AMPK, thus reducing blood glucose and insulin to levels observed in CR mice [58]. Metformin, as a monotherapy, suppresses tumor development and/or growth in multiple experimental models, including colon, mammary, and hematopoietic cancer models [59]. Metformin has shown promise both in preclinical and clinical studies, improving treatment of colon, breast, ovarian, prostate, and lung cancers [60, 61]. Several phase II trials are currently underway to evaluate metformin as a potential combination therapy, including one non-small cell lung cancer study that involves a low carbohydrate diet arm.

Resveratrol, a polyphenolic compound found in grapes, berries and, most famously, red wine, has also been under consideration as a CR mimetic. Resveratrol is believed to underlie the "French paradox," in which the consumption of red wine is believed to reduce mortality rates from cardiovascular disease and certain cancers [62]. Resveratrol displays anti-inflammatory, anti-oxidant, and anti-angiogenic [63] properties and suppresses development and growth of numerous cancer types in preclinical models, including breast, prostate, colon, and liver. Although several in vitro and in vivo studies have indicated that resveratrol can enhance anticancer treatments [64], Fukui et al. [65] suggested that resveratrol may actually reduce the efficacy of paclitaxel treatment in breast cancer. Therefore, more preclinical studies should be performed prior to progressing to clinical trials examining resveratrol as an adjuvant anticancer therapy.

An emerging $\mathrm{CR}$ mimetic is hydroxycitrate, a citric acid derivative and over-the-counter weight-loss drug that inhibits ATP citrate lyase, the enzyme that catalyzes the conversion of citrate into oxaloacetate and acetyl CoA. Cancer cells utilize acetyl CoA as a synthetic precursor to fuel proliferation and growth [66]; thus, blocking acetyl CoA synthesis is a rational approach to specifically target cancer metabolism. Furthermore, hydroxycitrate is a potent inducer of autophagy. Nevertheless, hydroxycitrate administration alone does not affect systemic glucose or insulin [67]. Further, although Pietrocola et al. [41] showed enhanced anticancer effects combining hydroxycitrate with doxorubicin and cyclophosphamide, a small trial revealed no added benefit of hydroxycitrate when administered with $\alpha$-lipoic acid alongside the standard of care [68].

\section{Alternative dietary approaches}

Further to the $C R$ mimetic drugs above, dietary regimens, such as low carbohydrate/ketogenic and intermittent energy restriction (IER), may be suitable alternatives to chronic $\mathrm{CR}$ in combination therapies. Low carbohydrate/ketogenic diets rewire energy metabolism to utilize ketones derived from fatty acids, in particular medium chain triglycerides, as an energy source rather than 
glucose. These diets mimic many of the metabolic and anti-inflammatory properties of $\mathrm{CR}$, including reduced blood glucose, insulin, and IGF-1 [69], as well as the oxidation of fatty acids and generation of ketones. The ketogenic diet has long been used successfully as a means to reduce epileptic seizures [70] and more recently in type 2 diabetes [71]. Further, studies have shown that the diet is well tolerated in cancer patients either as an adjuvant or monotherapy [72, 73]. Use as a monotherapy has been shown to halt progression of soft palate cancer [73], suggesting that, in some circumstances, a ketogenic diet alone may be sufficient for cancer management. Preclinical studies have shown promising results for low carbohydrate/ketogenic diets in reducing tumor growth in breast [74], prostate [75], brain [76], and gastric cancer models [77], and it has been shown to promote response to adjuvant radiation therapy [72]. In addition, a switch to a low carbohydrate/ketogenic diet has been shown to prevent cachexia in patients undergoing chemotherapy, suggesting this dietary approach may be a suitable alternative for cancer patients at risk of cachexia, sarcopenia, and weight loss [78].

IER, such as the 5-2 diet, in which an individual adheres to severe restriction ( $75 \%$ fewer calories) on 2 non-consecutive days while eating a normal, healthy diet on the remaining 5 days, has been a successful weight loss approach in human studies, and results in similar improvements in metabolic parameters such as insulin sensitivity [3]. A randomized trial is currently underway comparing IER and chronic CR in combination with taxane treatment in breast cancer patients. Preliminary results from this study suggest that IER is tolerable in patients receiving chemotherapy, and the outcome of this trial will add to the evidence for $\mathrm{CR}$ as a supportive treatment and evaluate IER as a feasible alternative to $\mathrm{CR}$ as an anticancer therapy.

\section{Conclusions}

Dietary interventions are attractive as inexpensive supportive anticancer therapies. CR is an established tumor preventative regimen, reducing systemic inflammation and growth factor signaling, as well as improving metabolic markers. Improved metabolism and inflammation are also likely mechanisms through which $\mathrm{CR}$ may reduce tumor growth and enhance therapeutic response (Fig. 1). In addition, oncogenic transformation and loss of senescence in cancer cells may render them more sensitive to CR than normal cells (Fig. 1). As chronic CR is contraindicated for many cancer patients at risk for weight loss, cachexia, and immunosuppression, intermittent CR, fasting-mimicking diets, low carbohydrate/ketogenic diets, or CR mimetic drugs may be more suitable. Fasting and

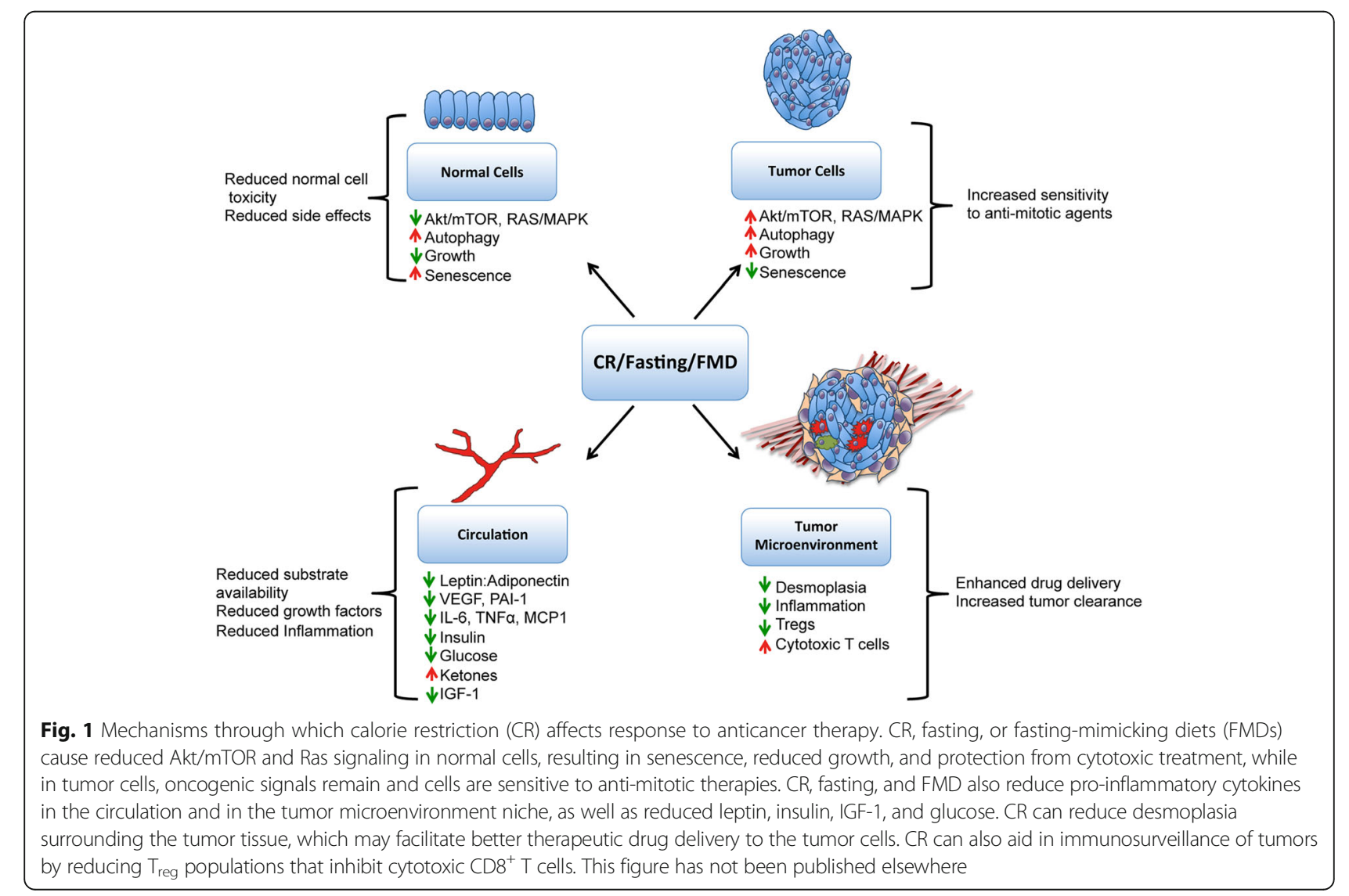


low carbohydrate diets have been shown to reduce side effects and to improve chemotherapy and radiation therapy in animal models, and there is great promise for these interventions in the clinic. More preclinical studies are required to determine in which cancers, at which stage, and in what combinations CR mimetic drugs may prove most effective. Future studies should take into consideration (1) the risk of cachexia in a patient population, whereby those at high risk may benefit from a ketogenic diet or short-term fasting; (2) the immunologic state of the enrolled patients, when CR or rapamycin treatment may be detrimental to wound healing or inflammatory responses; and (3) the metabolic state of patients, with diabetic patients in particular being at risk of adverse effects during chronic CR or fasting regimens, whereby treatment with metformin or a ketogenic diet may be of benefit. While in the short-term studies will need to focus on the safety and added benefit to current therapies, future studies may also focus on the potential of $\mathrm{CR}$ in enhancing the response to lower doses of chemotherapy and radiation therapy. In summary, CR and its mimetics show promise as supportive anticancer therapies. Clinical studies are ongoing and will inform on the potential use of these dietary and drug treatments alongside conventional treatments.

\section{Abbreviations}

AMPK: AMP kinase; CR: Calorie restriction; IER: Intermittent energy restriction; IGF-1: Insulin-like growth factor 1

\section{Acknowledgements}

This work was supported by grants from the National Cancer Institute (R35CA197627) and Breast Cancer Research Foundation to SD Hursting. $\mathrm{CH}$ O'Flanagan is supported by a fellowship from the American Institute for Cancer Research (11A003). SBM is supported by a T32 training fellowship from the National Institutes of Health (8T32LM012420-02).

\section{Authors' contributions}

CHO'F, LAS, SBM, and SDH wrote and approved the final manuscript.

\section{Competing interests}

The authors declare that they have no competing interests.

\section{Publisher's Note}

Springer Nature remains neutral with regard to jurisdictional claims in published maps and institutional affiliations.

\section{Author details}

'Department of Nutrition, University of North Carolina, Chapel Hill, NC 27517, USA. ${ }^{2}$ Lineberger Comprehensive Cancer Center, University of North Carolina, Chapel Hill, NC 27517, USA. ${ }^{3}$ Nutrition Research Institute, University of North Carolina, Kannapolis, NC 28081, USA. ${ }^{4}$ Department of Nutrition, University of North Carolina at Chapel Hill, 2100 Michael Hooker Research Center, Campus Box 7461, Chapel Hill, NC 27599, USA.

Received: 22 December 2016 Accepted: 15 May 2017

Published online: 24 May 2017

\section{References}

1. Berrigan D, Lavigne JA, Perkins SN, Nagy TR, Barrett JC, Hursting SD. Phenotypic effects of calorie restriction and insulin-like growth factor-1 treatment on body composition and bone mineral density of C57BL/6 mice: implications for cancer prevention. In Vivo. 2005;19(4):667-74.
2. Harvie MN, Pegington M, Mattson MP, Frystyk J, Dillon B, Evans G, Cuzick J, Jebb SA, Martin B, Cutler RG, et al. The effects of intermittent or continuous energy restriction on weight loss and metabolic disease risk markers: a randomized trial in young overweight women. Int J Obes. 2011;35(5):714-27.

3. Harvie MN, Sims AH, Pegington M, Spence K, Mitchell A, Vaughan AA, Allwood JW, Xu Y, Rattray NJ, Goodacre R, et al. Intermittent energy restriction induces changes in breast gene expression and systemic metabolism. Breast Cancer Res. 2016;18(1):57.

4. Hursting SD, Dunlap SM, Ford NA, Hursting MJ, Lashinger LM. Calorie restriction and cancer prevention: a mechanistic perspective. Cancer Metab. 2013;1 (1):10

5. Most J, Tosti V, Redman LM, Fontana L. Calorie restriction in humans: an update. Ageing Res Rev. 2016. doi:10.1016/j.arr2016.08.005.

6. Lv M, Zhu X, Wang H, Wang F, Guan W. Roles of caloric restriction, ketogenic diet and intermittent fasting during initiation, progression and metastasis of cancer in animal models: a systematic review and meta-analysis. PLoS One. 2014;9(12), el15147.

7. Mattison JA, Colman RJ, Beasley TM, Allison DB, Kemnitz JW, Roth GS, Ingram DK, Weindruch R, de Cabo R, Anderson RM. Caloric restriction improves health and survival of rhesus monkeys. Nat Commun. 2017;8:14063.

8. Harvey AE, Lashinger LM, Otto G, Nunez NP, Hursting SD. Decreased systemic IGF-1 in response to calorie restriction modulates murine tumor cell growth, nuclear factor-kappaB activation, and inflammation-related gene expression. Mol Carcinog. 2013;52(12):997-1006.

9. Lashinger LM, Malone LM, MCArthur MJ, Goldberg JA, Daniels EA, Pavone A, Colby JK, Smith NC, Perkins SN, Fischer SM, et al. Genetic reduction of insulin-like growth factor-1 mimics the anticancer effects of calorie restriction on cyclooxygenase-2-driven pancreatic neoplasia. Cancer Prev Res (Phila). 2011:4(7):1030-40.

10. Nogueira LM, Lavigne JA, Chandramouli GV, Lui H, Barrett JC, Hursting SD. Dose-dependent effects of calorie restriction on gene expression, metabolism, and tumor progression are partially mediated by insulin-like growth factor-1. Cancer Med. 2012;1 (2):275-88.

11. Harvey AE, Lashinger LM, Hays $D$, Harrison LM, Lewis K, Fischer SM, Hursting SD. Calorie restriction decreases murine and human pancreatic tumor cell growth, nuclear factor-kappaB activation, and inflammation-related gene expression in an insulin-like growth factor-1-dependent manner. PLoS One. 2014;9(5):e94151.

12. Bowers LW, Rossi EL, O'Flanagan CH, de Graffenried LA, Hursting SD. The role of the insulin/IGF system in cancer: lessons learned from clinical trials and the energy balance-cancer link. Front Endocrinol. 2015;6:77.

13. Chitnis MM, Yuen JS, Protheroe AS, Pollak M, Macaulay VM. The type 1 insulin-like growth factor receptor pathway. Clin Cancer Res. 2008;14(20):6364-70.

14. Denduluri SK, Idowu O, Wang Z, Liao Z, Yan Z, Mohammed MK, Ye J, Wei Q, Wang J, Zhao L, et al. Insulin-like growth factor (IGF) signaling in tumorigenesis and the development of cancer drug resistance. Genes Dis. 2015;2(1):13-25.

15. Hursting SD, Smith SM, Lashinger LM, Harvey AE, Perkins SN. Calories and carcinogenesis: lessons learned from 30 years of calorie restriction research. Carcinogenesis. 2010;31(1):83-9.

16. Mukherjee P, Abate LE, Seyfried TN. Antiangiogenic and proapoptotic effects of dietary restriction on experimental mouse and human brain tumors. Clin Cancer Res. 2004;10(16):5622-9.

17. Mukherjee P, Mulrooney TJ, Marsh J, Blair D, Chiles TC, Seyfried TN. Differential effects of energy stress on AMPK phosphorylation and apoptosis in experimental brain tumor and normal brain. Mol Cancer. 2008;7:37.

18. Mihaylova MM, Shaw RJ. The AMPK signalling pathway coordinates cell growth, autophagy and metabolism. Nat Cell Biol. 2011;13(9):1016-23.

19. Selman C, Kerrison ND, Cooray A, Piper MD, Lingard SJ, Barton RH, Schuster EF, Blanc E, Gems D, Nicholson JK, et al. Coordinated multitissue transcriptional and plasma metabonomic profiles following acute caloric restriction in mice. Physiol Genomics. 2006;27(3):187-200.

20. Lashinger LM, O'Flanagan CH, Dunlap SM, Rasmussen AJ, Sweeney S, Guo JY, Lodi A, Tiziani S, White E, Hursting SD. Starving cancer from the outside and inside: separate and combined effects of calorie restriction and autophagy inhibition on Ras-driven tumors. Cancer Metab. 2016;4:18.

21. Altman BJ, Stine ZE, Dang CV. From Krebs to clinic: glutamine metabolism to cancer therapy. Nat Rev Cancer. 2016;16(10):619-34.

22. Currie E, Schulze A, Zechner R, Walther TC, Farese Jr RV. Cellular fatty acid metabolism and cancer. Cell Metab. 2013;18(2):153-61.

23. Ward PS, Thompson CB. Metabolic reprogramming: a cancer hallmark even warburg did not anticipate. Cancer Cell. 2012;21(3):297-308. 
24. Allen BG, Bhatia SK, Anderson CM, Eichenberger-Gilmore JM, Sibenaller ZA, Mapuskar KA, Schoenfeld JD, Buatti JM, Spitz DR, Fath MA. Ketogenic diets as an adjuvant cancer therapy: History and potential mechanism. Redox Biol. 2014:2:963-70.

25. White E, Mehnert JM, Chan CS. Autophagy, metabolism, and cancer. Clin Cancer Res. 2015;21(22):5037-46.

26. Galluzzi L, Pietrocola F, Bravo-San Pedro JM, Amaravadi RK, Baehrecke EH, Cecconi F, Codogno P, Debnath J, Gewirtz DA, Karantza V, et al. Autophagy in malignant transformation and cancer progression. EMBO J. 2015;34(7):856-80.

27. Cheong H, Lu C, Lindsten T, Thompson CB. Therapeutic targets in cancer cell metabolism and autophagy. Nat Biotechnol. 2012;30(7):671-8.

28. Harvie M, Howell A. Energy restriction and the prevention of breast cancer. Proc Nutr Soc. 2012;71(2):263-75.

29. Imayama I, Ulrich CM, Alfano CM, Wang C, Xiao L, Wener MH, Campbell KL, Duggan C, Foster-Schubert KE, Kong A, et al. Effects of a caloric restriction weight loss diet and exercise on inflammatory biomarkers in overweight/ obese postmenopausal women: a randomized controlled trial. Cancer Res. 2012;72(9):2314-26.

30. Coussens LM, Werb Z. Inflammation and cancer. Nature. 2002;420(6917):860-7.

31. O'Flanagan CH, Bowers LW, Hursting SD. A weighty problem: metabolic perturbations and the obesity-cancer link. Horm Mol Biol Clin Investig. 2015;23(2):47-57.

32. Weiss EP, Racette SB, Villareal DT, Fontana L, Steger-May K, Schechtman KB, Klein S, Holloszy JO, Washington University School of Medicine CALERIE Group. Improvements in glucose tolerance and insulin action induced by increasing energy expenditure or decreasing energy intake: a randomized controlled trial. Am J Clin Nutr. 2006;84(5):1033-42.

33. Powolny AA, Wang S, Carlton PS, Hoot DR, Clinton SK. Interrelationships between dietary restriction, the IGF-I axis, and expression of vascular endothelial growth factor by prostate adenocarcinoma in rats. Mol Carcinog 2008;47(6):458-65.

34. Mulrooney TJ, Marsh J, Urits I, Seyfried TN, Mukherjee P. Influence of caloric restriction on constitutive expression of NF-kappaB in an experimental mouse astrocytoma. PLoS One. 2011;6(3):e18085.

35. Fontana L. Neuroendocrine factors in the regulation of inflammation: excessive adiposity and calorie restriction. Exp Gerontol. 2009;44(1-2):41-5.

36. Peters JM, Shah YM, Gonzalez FJ. The role of peroxisome proliferator-activated receptors in carcinogenesis and chemoprevention. Nat Rev Cancer. 2012;12(3):181-95.

37. Staudt LM. Oncogenic activation of NF-kappaB. Cold Spring Harb Perspect Biol. 2010;2(6):a000109.

38. Saleh AD, Simone BA, Palazzo J, Savage JE, Sano Y, Dan T, Jin L, Champ CE, Zhao S, Lim M, et al. Caloric restriction augments radiation efficacy in breast cancer. Cell Cycle. 2013;12(12):1955-63.

39. Lee C, Longo VD. Fasting vs dietary restriction in cellular protection and cancer treatment: from model organisms to patients. Oncogene. 2011;30(30):3305-16

40. Raffaghello L, Lee C, Safdie FM, Wei M, Madia F, Bianchi G, Longo VD. Starvation-dependent differential stress resistance protects normal but not cancer cells against high-dose chemotherapy. Proc Natl Acad Sci U S A. 2008;105(24):8215-20.

41. Pietrocola F, Pol J, Vacchelli E, Rao S, Enot DP, Baracco EE, Levesque S, Castoldi F, Jacquelot N, Yamazaki T, et al. Caloric restriction mimetics enhance anticancer immunosurveillance. Cancer Cell. 2016;30(1):147-60.

42. Lee C, Raffaghello L, Brandhorst S, Safdie FM, Bianchi G, Martin-Montalvo A, Pistoia V, Wei M, Hwang S, Merlino A, et al. Fasting cycles retard growth of tumors and sensitize a range of cancer cell types to chemotherapy. Sci Transl Med. 2012;4(124):124ra127.

43. Klement RJ, Champ CE. Calories, carbohydrates, and cancer therapy with radiation: exploiting the five R's through dietary manipulation. Cancer Metastasis Rev. 2014;33(1):217-29.

44. Longo VD, Panda S. Fasting, circadian rhythms, and time-restricted feeding in healthy lifespan. Cell Metab. 2016;23(6):1048-59.

45. Sancar A, Lindsey-Boltz LA, Gaddameedhi S, Selby CP, Ye R, Chiou YY, Kemp MG, Hu J, Lee JH, Ozturk N. Circadian clock, cancer, and chemotherapy. Biochemistry. 2015;54(2):110-23.

46. Lee C, Raffaghello L, Longo VD. Starvation, detoxification, and multidrug resistance in cancer therapy. Drug Resist Updat. 2012;15(1-2):114-22.

47. Di Biase S, Lee C, Brandhorst S, Manes B, Buono R, Cheng CW, Cacciottolo M, Martin-Montalvo A, de Cabo R, Wei M, et al. Fasting-mimicking diet reduces
HO-1 to promote T cell-mediated tumor cytotoxicity. Cancer Cell. 2016;30(1):136-46.

48. Wei M, Brandhorst S, Shelehchi M, Mirzaei H, Cheng CW, Budniak J, Groshen S, Mack WJ, Guen E, Di Biase S, et al. Fasting-mimicking diet and markers/ risk factors for aging, diabetes, cancer, and cardiovascular disease. Sci Transl Med. 2017:9(377):eaai870. doi:10.1126/scitrans/med.aai8700.

49. Cheng CW, Adams GB, Perin L, Wei M, Zhou X, Lam BS, Da Sacco S, Mirisola M, Quinn DI, Dorff TB, et al. Prolonged fasting reduces IGF-1/PKA to promote hematopoietic-stem-cell-based regeneration and reverse immunosuppression. Cell Stem Cell. 2014;14(6):810-23.

50. Farazi M, Nguyen J, Goldufsky J, Linnane S, Lukaesko L, Weinberg AD, Ruby CE. Caloric restriction maintains OX40 agonist-mediated tumor immunity and CD4 T cell priming during aging. Cancer Immunol Immunother. 2014;63(6):615-26.

51. Raffaghello L, Safdie F, Bianchi G, Dorff T, Fontana L, Longo VD. Fasting and differential chemotherapy protection in patients. Cell Cycle. 2010;9(22):4474-6.

52. Safdie FM, Dorff T, Quinn D, Fontana L, Wei M, Lee C, Cohen P, Longo VD. Fasting and cancer treatment in humans: a case series report. Aging. 2009;1 (12):988-1007.

53. Harrison DE, Strong R, Sharp ZD, Nelson JF, Astle CM, Flurkey K, Nadon NL, Wilkinson JE, Frenkel K, Carter CS, et al. Rapamycin fed late in life extends lifespan in genetically heterogeneous mice. Nature. 2009;460(7253):392-5.

54. Cifarelli V, Lashinger LM, Devlin KL, Dunlap SM, Huang J, Kaaks R, Pollak MN, Hursting SD. Metformin and rapamycin reduce pancreatic cancer growth in obese prediabetic mice by distinct microRNA-regulated mechanisms. Diabetes. 2015;64(5):1632-42.

55. Nogueira LM, Dunlap SM, Ford NA, Hursting SD. Calorie restriction and rapamycin inhibit MMTV-Wnt-1 mammary tumor growth in a mouse model of postmenopausal obesity. Endocr Relat Cancer. 2012;19(1):57-68.

56. Jiang BH, Liu LZ. Role of mTOR in anticancer drug resistance: perspectives for improved drug treatment. Drug Resist Updat. 2008;11(3):63-76.

57. Zhou Y, Zhao RH, Tseng KF, Li KP, Lu ZG, Liu Y, Han K, Gan ZH, Lin SC, $\mathrm{Hu} \mathrm{HY}$, et al. Sirolimus induces apoptosis and reverses multidrug resistance in human osteosarcoma cells in vitro via increasing microRNA-34b expression. Acta Pharmacol Sin. 2016;37(4):519-29.

58. Linden MA, Lopez KT, Fletcher JA, Morris EM, Meers GM, Siddique S, Laughlin MH, Sowers JR, Thyfault JP, Ibdah JA, et al. Combining metformin therapy with caloric restriction for the management of type 2 diabetes and nonalcoholic fatty liver disease in obese rats. Appl Physiol Nutr Metab. 2015;40(10):1038-47

59. Pollak MN. Investigating metformin for cancer prevention and treatment: the end of the beginning. Cancer Discov. 2012;2(9):778-90.

60. Hirsch HA, Iliopoulos D, Tsichlis PN, Struhl K. Metformin selectively targets cancer stem cells, and acts together with chemotherapy to block tumor growth and prolong remission. Cancer Res. 2009;69(19):7507-11.

61. Hiopoulos D, Hirsch HA, Struhl K. Metformin decreases the dose of chemotherapy for prolonging tumor remission in mouse xenografts involving multiple cancer cell types. Cancer Res. 2011;71(9):3196-201.

62. Catalgol B, Batirel S, Taga Y, Ozer NK. Resveratrol: French paradox revisited. Front Pharmacol. 2012;3:141.

63. Carter LG, D'Orazio JA, Pearson KJ. Resveratrol and cancer: focus on in vivo evidence. Endocr Relat Cancer. 2014;21(3):R209-25.

64. Gupta SC, Kannappan R, Reuter S, Kim JH, Aggarwal BB. Chemosensitization of tumors by resveratrol. Ann N Y Acad Sci. 2011;1215:150-60.

65. Fukui M, Yamabe N, Zhu BT. Resveratrol attenuates the anticancer efficacy of paclitaxel in human breast cancer cells in vitro and in vivo. Eur J Cancer. 2010;46(10):1882-91.

66. Hatzivassiliou G, Zhao F, Bauer DE, Andreadis C, Shaw AN, Dhanak D, Hingorani SR, Tuveson DA, Thompson CB. ATP citrate lyase inhibition can suppress tumor cell growth. Cancer Cell. 2005;8(4):311-21.

67. Thazhath SS, Wu T, Bound MJ, Checklin HL, Standfield S, Jones KL, Horowitz M, Rayner CK. Effects of intraduodenal hydroxycitrate on glucose absorption, incretin release, and glycemia in response to intraduodenal glucose infusion in health and type 2 diabetes: a randomised controlled trial. Nutrition. 2016;32(5):553-9.

68. Schwartz L, Buhler L, Icard P, Lincet $H$, Steyaert JM. Metabolic treatment of cancer: intermediate results of a prospective case series. Anticancer Res. 2014;34(2):973-80

69. Dupuis N, Curatolo N, Benoist JF, Auvin S. Ketogenic diet exhibits anti-inflammatory properties. Epilepsia. 2015;56(7):e95-8.

70. Martin K, Jackson CF, Levy RG, Cooper PN. Ketogenic diet and other dietary treatments for epilepsy. Cochrane Database Syst Rev. 2016;2:CD001903. 
71. Yancy Jr WS, Foy M, Chalecki AM, Vernon MC, Westman EC. A low-carbohydrate, ketogenic diet to treat type 2 diabetes. Nutr Metab. 2005;2:34.

72. Schwartz K, Chang HT, Nikolai M, Pernicone J, Rhee S, Olson K, Kurniali PC, Hord NG, Noel M. Treatment of glioma patients with ketogenic diets: report of two cases treated with an IRB-approved energy-restricted ketogenic diet protocol and review of the literature. Cancer Metab. 2015;3:3.

73. Tóth C, Clemens Z. Halted progression of soft palate cancer in a patient treated with the paleolithic ketogenic diet alone: a 20-months follow-up. Am J Med Case Rep. 2016;4(8):288-92.

74. Ho WW, Leung K, Hsu A, Luk B, Lai J, Shen SY, Minchinton Al, Waterhouse D, Bally MB, Lin W, et al. A low carbohydrate, high protein diet slows tumor growth and prevents cancer initiation. Cancer Res. 2011;71(13):4484-93.

75. Caso J, Masko EM, li JA, Poulton SH, Dewhirst M, Pizzo SV, Freedland SJ. The effect of carbohydrate restriction on prostate cancer tumor growth in a castrate mouse xenograft model. Prostate. 2013;73(5):449-54.

76. Stafford P, Abdelwahab MG, Kim DY, Preul MC, Rho JM, Scheck AC. The ketogenic diet reverses gene expression patterns and reduces reactive oxygen species levels when used as an adjuvant therapy for glioma. Nutr Metab. 2010;7:74.

77. Otto C, Kaemmerer U, Illert B, Muehling B, Pfetzer N, Wittig R, Voelker HU, Thiede A, Coy JF. Growth of human gastric cancer cells in nude mice is delayed by a ketogenic diet supplemented with omega-3 fatty acids and medium-chain triglycerides. BMC Cancer. 2008;8:122.

78. Tisdale MJ, Brennan RA, Fearon KC. Reduction of weight loss and tumour size in a cachexia model by a high fat diet. Br J Cancer. 1987;56(1):39-43.

79. de Groot S, Vreeswijk MP, Welters MJ, Gravesteijn G, Boei JJ, Jochems A, Houtsma D, Putter H, van der Hoeven JJ, Nortier JW, et al. The effects of short-term fasting on tolerance to (neo) adjuvant chemotherapy in HER2-negative breast cancer patients: a randomized pilot study. BMC Cancer. 2015;15:652

\section{Submit your next manuscript to BioMed Central and we will help you at every step:}

- We accept pre-submission inquiries

- Our selector tool helps you to find the most relevant journal

- We provide round the clock customer support

- Convenient online submission

- Thorough peer review

- Inclusion in PubMed and all major indexing services

- Maximum visibility for your research

Submit your manuscript at www.biomedcentral.com/submit

C) Biomed Central 